This item was submitted to Loughborough's Research Repository by the author.

Items in Figshare are protected by copyright, with all rights reserved, unless otherwise indicated.

\title{
State capitalism revisited: a review of emergent forms and developments
}

PLEASE CITE THE PUBLISHED VERSION

https://doi.org/10.1080/00213624.2019.1606653

\section{PUBLISHER}

Taylor \& Francis $@$ Journal of Economic Issues /Association for Evolutionary Economics

\section{VERSION}

AM (Accepted Manuscript)

\section{PUBLISHER STATEMENT}

This is an Accepted Manuscript of an article published by Taylor \& Francis in Journal of Economic Issues on 13 May 2019, available online: https://doi.org/10.1080/00213624.2019.1606653

\section{LICENCE}

CC BY-NC-ND 4.0

\section{REPOSITORY RECORD}

Dolfsma, Wilfred, and Anna Grosman. 2019. "State Capitalism Revisited: A Review of Emergent Forms and Developments”. figshare. https://hdl.handle.net/2134/37234. 


\title{
STATE CAPITALISM REVISITED: A REVIEW OF EMERGENT FORMS AND DEVELOPMENTS ${ }^{1}$
}

Journal of Economic Issues, 2019

\author{
ACCEPTED MANUSCRIPT
}

\section{Wilfred Dolfsma}

\section{Anna Grosman}

\begin{abstract}
Even when the neoliberal ideology of the free market was more dominant than it now is, the state was involved in economic activities that could be undertaken by private firms. State capitalism takes increasingly diverse forms, including beyond direct, partial or even indirect ownership. This paper briefly reviews some of these forms without claiming to be exhaustive as the shape state capitalism takes differs widely across the institutionalized contexts of countries. We assess state capitalism using double movement framework and argue that this framework needs adaptation to novel forms of state capitalism that include, e.g., state-owned multinationals and sovereign wealth funds.
\end{abstract}

JEL codes: B25, B52, B55, H70, P50

\section{Introduction}

\footnotetext{
${ }^{1}$ Wilfred Dolfsma is full professor and chairholder at Wageningen University \& Research, Wageningen, The Netherlands, wilfred.dolfsma@wur.nl, www.wilfreddolfsma.net. Anna Grosman (corresponding author) is lecturer in innovation and entrepreneurship at the Institute of Innovation and Entrepreneurship, Loughborough University London, UK, a.grosman@lboro.ac.uk, www.annagrosman.com. Authors are listed alphabetically and equally contributed to the development of this article.
} 
State involvement in economic activities that private parties could as well take up may assume a wide range of forms, not all of which are necessarily benign. The back and forth between privatizations (1980s) and nationalizations (in some countries in particular in the 2010s) resulted in new, hybrid, and more complex realities of the influence of government in the economy, substantially different from state-owned enterprises (SOEs) focusing on controlling the means of production that operated into the 1970s. These shifts reflect a historical dynamic in which countries move between marketization at one end of the spectrum and state involvement in firms (statism) at the other end. The perceived inability of market system to ensure stability and equality has led to suggestions that the movement back to statism is predictable, and even overdue. At first, Polanyi's concept of 'double movement', where state intervenes to deal with the adverse consequences of a self-regulated market system, appears to be as pertinent as ever. The protection now sought for society by the state against the effects of self-regulated market is defined by market logic, however, mostly via ownership. Governments have taken on new roles as global asset managers. One could question whether such market-based attempts at regulation allow for social protection of the vulnerable in society - we explore the extent it is likely to be. We here review new forms and trends of statism in view of Polanyi's double movement.

\section{State and Market: Unhinging Polanyi}

Many a theory in economics, politics and elsewhere implicitly assumes that market and society are quite separate. While some strands of thought believe that expanding the economic sphere is to be welcomed and even promoted, others, including ones inspired by Karl Polanyi, argue that society and social individuals should be protected from developments in the economic sphere. What is more, leaving the market to develop at its own discretion, and others argue, "implied a stark utopia". Instead, Polanyi would argue that leaving the market to itself leads to an "avalanche of social dislocation" (p.40). The market system or economic sphere constitutes a very particular "institutional pattern" (p.41) or set of principles (p.132) leading to a "divorcedness of a separate economic motive from the social relations" (p.54).

As Polanyi sees an "institutional separation of society into an economic and political sphere" (p.71), society needs to be protected by political means from encroachment by the economic sphere in what he refers to as a 'double movement' (p.132). If not, human society would be 'annihilated' (p.76). 'Powerful institutions' are needed to 'check the action of the 
market' which has a tendency or is 'self-destructive' in nature (p.76). Protecting society from the vagaries of the market would need to involve "remov[-ing] the elements of production land, labor, and money - from the market" (p.252).

So, what does it mean to see the state, or the political sphere, actively stimulate and even enter the economic sphere, adopting its rationale at least in part, in a movement we refer to as 'state capitalism'? We argue that where, and to the extent that states are involved in state capitalism, one of three (3) conclusions is warranted. Perhaps, first, the state can be seen to adopt the principles of the market in order to more efficiently generate resources to help support society. Another possibility is that the state (pre-emptively) enters a part of what is or might become an economic sphere, but a sphere if left to the market that impacts society quite profoundly yet cannot or cannot efficiently enough be organised solely from within the societal (political) sphere and so some market logic should be employed - provision of blood for donation may be an example of this. A possible third interpretation is that the state actively leaves parts of the system to an economic sphere without leaving the governance of those parts fully following market principles. At the very least these possible interpretations imply that what might once have been a clear distinction between market and society is not so clear a distinction (anymore). The variegated phenomenon we refer to as state capitalism also, even more, means that the different logics ruling both spheres either (1) mix, or (2) are alternately and perhaps unexpectedly invoked.

Let us investigate each of these options. Some suggest the different logics cannot mix, as the market is about parties seeking to pursue their self-interest, and politics or society is about defining and protecting individuals as citizens with equal rights. The defining and protecting of citizens are done through the formulation of laws which institutional economists may refer to as formal institutions. The logic of the laws for citizens may not per se be different from the logic of the laws formulated, implemented and policed for parties as economic agents, however. The content of laws governing different practices may clash(Dolfsma 2013)(Dolfsma 2013)(Dolfsma 2013)(Dolfsma 2013)(Dolfsma 2013)(Dolfsma 2013)(Dolfsma 2013)(Dolfsma 2013), but the logics need not. Most legal systems have developed ways to deal with conflicting demands from a legal system - to prevent government failure.

If the latter situation applies, where logics of market or society are alternately and perhaps unexpectedly invoked, however, a kind of government failure follows . This will 
create uncertainty, potentially hampering the flourishing of state capitalist forms in several ways depending on the shape state capitalism takes. If state capitalism takes the shape of undertaking continuous activities, especially requiring regular investment, the advantages of having access to a capital market offering diverse services might be diminished. If state capitalism takes the shape of investment in market activities, considerations when making decisions on how to invest might reflect the ambiguity about the logic governing the decisions. SWF returns are typically lower than those of other investment vehicles as a result, for instance .

Just how state capitalism is governed, as a mix or as alternating logics, reflects the nature of the country where the state capitalist activities are undertaken, we argue. Where a mix of logics prevails, through balancing in the legal arrangement sought for the state capitalist activities, regular economic activities are more likely to be governed by the rule of law as well. Where alternating logics prevail, regular economic activities are more likely to be confronted with formal institutions that offer a less predictable environment as the regulations that regulate a practice cannot be predicted in advance with sufficient detail. Such an environment is less conducive to stimulating economic activities.

\section{Forms and Recent Developments in State Capitalism}

State capitalism varies substantially across the globe, and even mature liberal markets have become more statist. Brazil, Russia, India, China and other emerging economies have substantial state involvement in their economies, which has in part legitimized state capitalism. The literature ignores differences between state capitalism across countries, as studies are country-specific.

Over the past 25 years, new forms of state capitalism developed that differ from stateowned enterprises (SOEs) operating into the 1970s and the 1980s. The new state capitalism is 'a form of bureaucratically engineered capitalism particular to each government that practices it' . Table 1 provides an overview of new forms state capitalism takes - we refer to stateaffiliated organizations, which include State Owned Enterprises (SOEs). State-affiliated organizations may show professional standards of corporate governance, improved operational efficiency and have an explicit market orientation, but can also be used by the state to achieve 
political and ideological goals . In recent years, State Owned MNCs (SOMNCs) have become more important.

$$
<<\text { Table } 1 \text { about here }>>
$$

Because of the heterogeneity of state capitalism across countries and differing institutional settings, generalization is problematic. In China, the state took a 'gradualist' approach to state capitalism, preserving state control while implementing capitalist institutional forms. In the 1980s, China decentralized state control to provincial, municipal, township and village-level governments, at the same time allowing the private sector to emerge . China developed a complex system of state capitalism where SOEs expanded operations at the expense of private firms. ${ }^{i}$ In 2000, China launched its 'Go Global' policy, establishing some SOEs as 'national champions', creating Chinese SOMNCs (e.g., DP World management of ports, CNOOC acquisition of SUNOCO). State involvement in listed SOEs was enabled by the often overlapping dual governance structure: the classic corporate board and the Party Committee, a unique structure headed by its Party Secretary. State debt financing and appointment of state officials to the board are popular means of state control beyond ownership. China's state capitalism is also characterized by strong presence of private business-state networks (guanxi). ${ }^{\text {ii }}$

State capitalism in Russia would be dramatically underestimated if we considered just direct ownership. ${ }^{\text {iii }}$ Appointment of acting government officials as board members and appointment of former government officials as top executives of companies with partial or indirect state ownership enhances state control occurs as well. The Russian state may also own a 'golden share' that gives a veto right to the state . Large companies in 'strategically important' industries may be dependent on state debt financing. ${ }^{\text {iv }}$

The US and particularly the UK privatized national production assets in the 1970s and 1980s which led to dispersed ownership and little state involvement, but a return of populist ideologies makes state capitalism the center of debate again. Host country populist politicians have presented state-owned multinationals (SOMNCs) and national champions from emerging economies as an economic and political threat, exacerbated by corruption scandals due to the close relationships between the state and SOEs .

The EU countries were able to better preserve the leadership role of state built on alignment of interests between the state and top management of privatized SOEs. Formerly 
state-owned monopolies were transformed into new (centralized or collaborative) hierarchies characterized by diversified constituency of blockholders, including financial institutions, industrial holdings and private shareholders.

There is a trend for states to invest in targets indirectly through the private equity fund it owns . Sovereign Wealth Funds (SWFs) tend to invest the majority of their capital internationally, to diversify macroeconomic and political exposures and avoid a domestic asset price bubble. ${ }^{\mathrm{v}}$ It is mostly developed economies that attract SWF investments, however . SWFs can have biases in their investment decisions. ${ }^{\text {vi }}$ SWFs purposes include both state- and firmlevel financial objectives, but potentially also strategic national development, political, and social initiatives. There may be a tension between these differing objectives. ${ }^{\text {vii }}$

\section{Extending and Qualifying Polanyi}

How to extend Polanyi's (1944) double movement framework to apply it to new forms of statism? For Polanyi involvement is restricted to state control via direct ownership of production facilities. Polanyi's framework may not address the challenges that arise due to the emergence of new, more subtle means of state involvement in markets. Subtle means of influence, such as debt financing, board seats, veto rights, and corporate political connections have emerged in recent decades in particular. SOMNCs in particular pose a challenge to Polanyi's framework. Economic, and also ideological or political logics exist for SOMNCs -. SOMNCs may solve market imperfections when the private sector has little incentive to provide the goods in the amount or price that is needed for the country and may be natural monopolies. ${ }^{\text {viii }}$ Political objectives for SOMNCs are varied. ${ }^{\text {ix }}$ Political objectives for SOMNCs are stronger when the state dislikes of private property or dislikes powerful interests, but can lead to centralization of property and power among politicians. Governance of organizations where indirect state-ownership or state-affiliation beyond ownership is involved can be opaque, giving rise to multilevel agency conflicts and obscuring SOMNCs' intentions.

Recent examples of state capitalism indicate that the state can have objectives for its economic activities beyond protection of its own society. Comparing different forms state capitalism takes across countries (cf. helps suggest how Polanyi's framework can be qualified and extended. In China and Russia, in particular, motives for their model of state capitalism are partly unrelated stability and growth. ${ }^{\mathrm{x}}$ While China has succeeded at bringing growth, Russia has lagged behind.$^{\mathrm{xi}}$ At the other end of the spectrum, classic liberal market economies such as UK and US are characterized by a much bigger dichotomy between state and market. 
Since the privatization of state assets, there is not much evidence of success in joint statebusiness activities in the UK. ${ }^{\text {xii }}$ The UK and US states manage the finance, welfare, health and education systems, and some assets of strategic importance such as transport and postal services, rather than, as Polanyi argues, protecting citizen against the evils of capitalism through state ownership of production more broadly. The coordinated market economies of the continental and northern EU countries in particular share a tradition of joint successful activities between the state and the business .

To us this suggests that a functional co-existence or even co-working of state and market more directly as in the recent examples we reviewed rely crucially for their success on being predicated on an institutionalized history of joining forces. Without the practices that emerge and are tested in the course of such a history, in particular the potentially conflicting logics of each domain may not be reconciled. This is why re-nationalizations in countries with limited history of collaborative state capitalist arrangements is dangerous rhetoric.

\section{Conclusion}

Recent forms of state capitalism require that institutional economists qualify and extend Polanyi's conceptual framework. A clear separation of state and economic spheres with their different logics and sets of principles no longer holds, if it ever did. There is a great variety of forms in which state intervenes in the economy, well beyond the direct ownership of productive assets used by Polanyi. This short paper suggests that the way in which the logics are combined, to be successful, is critically dependent on the institutional shape this takes. Future research can, first, study the way in which state capitalism works. Secondly, other, more indirect forms of state capitalism beyond ownership should be studied in micro detail. 


\section{References}

Aharoni, Yair. Evolution and Management of State-Owned Enterprises. Cambridge, MA: Ballinger, 1986.

Bortolotti, Bernardo, Veljko Fotak, and William L Megginson. "The Sovereign Wealth Fund Discount: Evidence from Public Equity Investments." The Review of Financial Studies 28, no. 11 (2015): 2993-3035.

Bremmer, Ian. The End of the Free Market: Who Wins the War between States and Corporations? New York, NY: Portfolio, 2010.

Chen, Victor Zitian, Aldo Musacchio, and Sali Li. "A Principals-Principals Perspective of Hybrid Leviathans: Cross-Border Acquisitions by State-Owned Mnes." Journal of Management (2018).

Chhaochharia, Vidhi, and Luc Laeven. "The Investment Allocation of Sovereign Wealth Funds." 2009.

Cuervo-Cazurra, Alvaro, Andrew Inkpen, Aldo Musacchio, and Kannan Ramaswamy. "Governments as Owners: State-Owned Multinational Companies." Springer, 2014.

Cui, Lin, and Fuming Jiang. "State Ownership Effect on Firms' Fdi Ownership Decisions under Institutional Pressure: A Study of Chinese Outward-Investing Firms." Journal of International Business Studies 43, no. 3 (2012): 264-84.

Delios, Andrew, Zhi Jian Wu, and Nan Zhou. "A New Perspective on Ownership Identities in China's Listed Companies." Management and Organization Review 2, no. 3 (2006): 319-43.

Dolfsma, Wilfred. Government Failure: Society, Markets and Rules. Cheltenham, UK: Edward Elgar Publishing, 2013.

Dolfsma, Wilfred, John Finch, and Robert McMaster. "Market and Society: How Do They Relate, and How Do They Contribute to Welfare?". Journal of Economic Issues 39, no. 2 (2005): 347-56.

Dolfsma, Wilfred, and Rudi Verburg. "Structure, Agency and the Role of Values in Processes of Institutional Change." Journal of Economic Issues 42, no. 4 (2008): 1031-54.

Duanmu, Jing-Lin. "State-Owned Mncs and Host Country Expropriation Risk: The Role of Home State Soft Power and Economic Gunboat Diplomacy." Journal of International Business Studies 45, no. 8 (2014): 1044-60.

Dyck, Alexander, and Adair Morse. "Sovereign Wealth Fund Portfolios." In Chicago Booth Research Paper Series. Chicago University: Chicago Booth, 2011.

Fernandes, Nuno. "Sovereign Wealth Funds: Investment Choices and Implications around the World." (2011).

Fotak, Veljko, Xuechen Gao, and William L Megginson. "A Financial Force to Be Reckoned With? An Overview of Sovereign Wealth Funds ". In The Oxford Handbook of Sovereign Wealth Funds, edited by D. J. Cumming, Geoffrey Wood, I. Filatotchev and J. Reinecke. Oxford, United Kingdom: Oxford University Press, 2017.

Frye, Timothy M, and Ichiro Iwasaki. "Government Directors and Business-State Relations in Russia." European Journal of Political Economy 27, no. 4 (2011): 642-58.

Grosman, Anna, and Aija Leiponen. "Organizational Transparency and Power in Firm Ownership Networks." Journal of Comparative Economics (2018).

Grosman, Anna, Ilya Okhmatovskiy, and Mike Wright. "State Control and Corporate Governance in Transition Economies: 25 Years on from 1989." Corporate Governance: An International Review 24, no. 3 (2016): 200-21.

Hodgson, Geoffrey M. "Karl Polanyi on Economy and Society: A Critical Analysis of Core Concepts." Review of Social Economy 75, no. 1 (2017): 1-25. 
Hoskisson, Robert E, Mike Wright, Igor Filatotchev, and Mike W Peng. "Emerging Multinationals from Mid-Range Economies: The Influence of Institutions and Factor Markets." Journal of Management Studies 50, no. 7 (2013): 1295-321.

Johan, Sofia A, April Knill, and Nathan Mauck. "Determinants of Sovereign Wealth Fund Investment in Private Equity Vs Public Equity." Journal of International Business Studies 44, no. 2 (2013): 155-72.

Liang, Hao, Bing Ren, and Sunny Li Sun. "An Anatomy of State Control in the Globalization of State-Owned Enterprises." Journal of International Business Studies 46, no. 2 (2015): 223-40.

Nguyen, Thuy Thu, and Mathijs A Van Dijk. "Corruption, Growth, and Governance: Private Vs. State-Owned Firms in Vietnam." Journal of Banking \& Finance 36, no. 11 (2012): 2935-48.

Poczter, Sharon, Aldo Musacchio, and Sergio G Lazzarini. "How to Compete against the New Breed of National Champions." MIT Sloan Management Review 59, no. 4 (2018): 65-70.

Polanyi, Karl. The Great Transformation: The Political and Economic Origins of Our Time. 2nd ed. Boston, MA: Beacon Press, 1957.

- The Great Transformation: The Political and Economic Origins of Our Time. 1st ed. New York, US: Farrar \& Rinehart, 1944.

Soskice, David W, and Peter A Hall. Varieties of Capitalism: The Institutional Foundations of Comparative Advantage. Oxford University Press Oxford, 2001.

Thun, Eric. "Industrial Policy, Chinese-Style: Fdi, Regulation, and Dreams of National Champions in the Auto Sector." Journal of East Asian Studies 4, no. 3 (2004): 45389.

Tkachenko, Andrey, Andrei Yakovlev, and Aleksandra Kuznetsova. "'Sweet Deals': StateOwned Enterprises, Corruption and Repeated Contracts in Public Procurement." Economic Systems 41, no. 1 (2017): 52-67.

Vasudeva, Gurneeta, Lilac Nachum, and Gui-Deng Say. "A Signaling Theory of Institutional Activism: How Norway's Sovereign Wealth Fund Investments Affect Firms' Foreign Acquisitions." Academy of Management Journal 61, no. 4 (2018): 1583-611.

Vernon, Raymond. "The International Aspects of State-Owned Enterprises." Journal of International Business Studies 10, no. 3 (1979): 7-14.

Villani, Elisa, Luciano Greco, and Nelson Phillips. "Understanding Value Creation in PublicPrivate Partnerships: A Comparative Case Study." Journal of Management Studies 54, no. 6 (2017): 876-905.

Wang, Junmin, Doug Guthrie, and Zhixing Xiao. "The Rise of Sasac: Asset Management, Ownership Concentration, and Firm Performance in China's Capital Markets." Management and Organization Review 8, no. 2 (2012): 253-82.

Wood, Geoffrey, and Mike Wright. "Corporations and New Statism: Trends and Research Priorities." The Academy of Management Perspectives 29, no. 2 (2015): 271-86. 
Table 1: Forms of State Capitalism

\begin{tabular}{|c|c|}
\hline $\begin{array}{l}\text { Form of State } \\
\text { Control }\end{array}$ & Characteristics \\
\hline $\begin{array}{l}\text { State Control } \\
\text { through Ownership }\end{array}$ & $\begin{array}{l}\text { Full Ownership } \\
\text { Minority Ownership } \\
\text { Partial Ownership (stakes in part of private firms [includes de facto } \\
\text { renationalization]) } \\
\text { Indirect Ownership (e.g., SWFs, investment funds) }\end{array}$ \\
\hline $\begin{array}{l}\text { Means of State } \\
\text { Control beyond } \\
\text { Ownership }\end{array}$ & $\begin{array}{l}\text { Debt or soft budget constraints } \\
\text { Appointments of current/past state officials to director } \\
\text { Dual governance of board and Party } \\
\text { Passive or active state involvement in governance } \\
\text { Regulatory involvement (capture) } \\
\text { Time-limited contracts (and re-contracting) } \\
\text { Veto rights (golden shares) }\end{array}$ \\
\hline $\begin{array}{l}\text { Formal and } \\
\text { informal political } \\
\text { connections }\end{array}$ & $\begin{array}{l}\text { Private business-state networks (guanxi; oligarchs) } \\
\text { Formal or informal political relationships } \\
\text { Shifting power relationships: state-capture vs business capture }\end{array}$ \\
\hline Internationalization & SOEs, SWFs acquire firms beyond national borders \\
\hline
\end{tabular}

Adapted from Grosman, Okhmatovskiy and Wright (2016)

\footnotetext{
' This is a process described as 'guo jin min tui'/ 'the state advances, the private sector retreats' Delios, Wu, and Zhou, 2006 Gradualism allowed the state to retain a stabilizing role and created incentives in SOEs similar to managers of large industrial firms (Grosman, Okhmatovskiy, and Wright, 2016).

ii Such political connections helped business tycoons to amass wealth especially in real estate, finance, high tech and mining.

iii Indirect state ownership through holding companies owned by the state such as UES and Svyazinvest as well as aggressive acquisition strategies of SOEs such as Gazprom, Rosneft and VTB is prominent.

iv Sanctions against Russia have most likely increased state capitalism by this means. Recently, shifting power relationships from business to state capture indicated the increasing power of state over oligarchs.

$\checkmark$ There are exceptions. In September 2018, Turkish President Recep Tayyip Erdogan appointed himself as Chairman of the country's SWF, and named finance minister and son-in-law Berat Albayrak as his deputy. The \$50bn wealth fund owns stakes in Turkish Airlines, state oil and pipeline companies, and Turkey's stock exchange, among others.

${ }^{v i}$ SWFs can, for instance, invest in markets that share a common (religious) culture, focus on specific regions or industries, or focus on low-risk assets (Chhaochharia and Laeven, 2009; Dyck and Morse, 2011).

vii Studies comparing cross-border investment strategies of SWFs to other private institutional investors found that SWFs behave differently in terms of choice (private or public equity investments) (Johan, Knill, and Mauck, 2013), risk appetite and returns (Fernandes, 2011; Dyck and Morse, 2011).

viii Instances of the former are in the defense and infrastructure industries, such as French-owned Airbus, Kuwait's Agility Public Warehousing Company and Singapore's Capital and Limited, while instances of the latter are in transport such as Germany's Volkswagen; oil \& gas, such as Norway's Equinor and Russia's Gazprom; or utilities, such as French-owned EDF (Vasudeva, Nachum, and Say, 2018).

ix Political motives to support SOMNCs may consist of support for politicians from the electorate, directly (building coalitions of interest groups dependent on a government such as public sector unions and state employees) or indirectly (subsidies and financing of activities that favor [some] voters [more than others]). Note that targeted interest groups (e.g., employees, unions) can become political force themselves, and unintended
} 
Dolfsma and Grosman (2019) AFEE (Journal of Economic Issues) @ ASSA

transfers of resources to secure support may occur (e.g., subsidies intended for the poor favoring middle and upper classes).

x In Russia, geopolitical dominance in neighboring, former USSR countries, but also projecting influence globally, has been on the agenda at least since President Vladimir Putin came into his third term in 2012. In China, an even bigger effort by the state has been directed at making China the largest economic power in the world, first by strengthening the internal consumer market, and then by providing incentives to both state-owned and private 'national champions' to internationalize.

${ }^{x i}$ Russia has lagged behind primarily due to low diversification of its economy and overreliance on oil \& gas production and prices on the international market. Russia's substantial state-affiliated sector is more stable and cash-rich comparing to the private sector, however, but both are dependent on strong corporate political ties to survive and prosper.

xii The collapse and liquidation of Carillion in the UK is a good recent example of this. 